\title{
The Anthropozoic era revisited
}

\author{
Valentí Rull \\ Institute of Earth Sciences Jaume Almera (ICTJA-CSIC), C. Solé i Sabarís $s / n, 08028$ Barcelona \\ Spain
}

\begin{abstract}
This paper explains in some detail the poorly known proposal of Stoppani (1873) regarding the Anthropozoic era, whose beginning was defined by the first traces of human presence on Earth. This author set the stratigraphic bases for the definition of the "human era", but the proposal had two main weaknesses: the dismissal of biological evolution and the lack of an absolute chronology. Further developments in radiometric/paleomagnetic dating and the elucidation of the main trends and timing of human evolution have provided the necessary information to update the original Anthropocene proposal in chronological terms, maintaining Stoppani's original definition and stratigraphic markers. This updated proposal follows the rules of the International Stratigraphic Guide and situates the beginning of the Anthropozoic era at the beginning of the Quaternary, when the first human fossils, corresponding to the first species of the genus Homo, and their cultural manifestations have been identified and dated. Therefore, the new Anthropozoic era would follow the Cenozoic era, which ended with the Neogene period. Defined in this way, the Quaternary period and its Pleistocene and Holocene epochs would be situated in the new Anthropozoic era. The main advantages of the updated Anthropozoic proposal are discussed and compared with the Anthropocene proposal, which is currently in progress. It is suggested that the updated Anthropozoic proposal might be fully elaborated to evaluate whether it would be submitted to the International Commission on Stratigraphy and the International Union of Geological Sciences for its eventual formalization.
\end{abstract}

\section{Keywords}

Anthropozoic, Anthropocene, Cenozoic, Quaternary, formalization, stratigraphy, human era, human evolution, absolute dating

\section{Introduction}

A number of terms have been coined to label the time span characterized by the increasing human impact on the Earth. Some of these names have a merely historical meaning (e.g., Neolithic Revolution, Industrial Revolution, Great Acceleration, Atomic Age), but others bear evident stratigraphic connotations. This is the case of the terms that include the prefix anthropo- (meaning human), followed by terminations reserved the formal units of the International Chronostratigraphic Chart (ICC) (Cohen et al., 2013) corresponding to erathems/eras ("Anthropozoic"), systems/periods ("Anthropogene") and series/epochs ("Anthropocene"). These names are usually written in quotation marks because they are informal terms, that is, terms that have not been formalized by the International Commission on Stratigraphy (ICS) and the International Union of Geological Sciences (IUGS), following the rules of the International Straigraphic Guide (ISG) (Murphy \& Salvador, 1999). Of the abovementioned informal names, only the "Anthropocene" (Crutzen \& Stoermer, 2000) is under study for formalization. The "Anthropogene" was unsuccessfully proposed as a synonym for the Quaternary (Gerasimov, 1979), whereas the "Anthropozoic" (Stoppani, 1873) has never been considered for formalization. 
The Anthropocene Working Group (AWG) was created in 2009 to prepare a report to be submitted to the ICS for the formalization of the Anthropocene as a new series/epoch following the Holocene. For such formalization, the ICS requires the definition of a standard stratigraphic section (stratotype) that characterizes the Anthropocene and distinguishes it from the Holocene on the basis of specific stratigraphic markers (e.g., lithology, fossils, physicochemical features). The basal level of this stratotype is known as the Global Stratotype Section and Point (GSSP) and should be recognizable (or correlatable) worldwide and globally synchronous (Murphy \& Salvador, 1999; Lucas, 2018). To date, the AWG has been able to define a possible beginning of the Anthropocene - 1945 CE (Fig. 1) - and the stratigraphic markers to characterize it - the radionuclides produced by the first atomic explosions - and is now looking for the most suitable stratotype to define the corresponding GSSP (Zalasiewicz et al., 2017a; Waters et al., 2018). According to Jan Zalasiewicz, the AWG convenor, the final proposal may still need some more years to be presented for formalization (Rull, 2018a). Fulfilling the quoted chronostratigraphic requirements, however, does not guarantee an automatic formalization of the Anthropocene since the proposal should be approved by the ICS and ratified by the IUGS after detailed scientific analysis of the evidence. Since several years ago, there has been an intense debate between the AWG (Waters et al., 2014, 2016; Zalasiewicz et al., 2016, 2017b) and members of the ICS and the IUGS (Finney, 2014; Gibbard \& Walker, 2014; Edwards, 2015; Walker et al., 2015; Finney \& Edwards, 2016), which suggests that, in its current form (Fig. 1), the AWG proposal might not be approved (Rull, 2018a).

The term "Anthropocene" was coined by Crutzen \& Stoermer (2000) using environmental rather than stratigraphic criteria. These authors discussed a possible beginning for the new epoch in the latter $18^{\text {th }}$ century, coinciding with the onset of the Industrial Revolution and the ensuing increase of atmospheric $\mathrm{CO}_{2}$ and other industrialization indicators. However, Crutzen \& Stoermer (2000) did not dismiss the possibility of including the entire Holocene within the Anthropocene concept. Others considered that the first global manifestations of human impact on the Earth system, which still is the main criterion to define the Anthropocene series/epoch, occurred in the Early-Mid Holocene as a consequence of the Neolithic Revolution, which produced the first significant increases of atmospheric greenhouse gases (Ruddiman, 2003, 2013). This has been called the early Anthropocene proposal. It has also been proposed that the Anthropocene may have started with the Great Acceleration (mid-20 ${ }^{\text {th }}$ century), where the environmental impacts initiated by the Industrial Revolution exacerbated. This proposal coincides, in chronological terms, with the Atomic Age and the AWG proposal in its present state. Other proposals exist that will not be discussed here (Lewis \& Masin, 2015, 2018), but all of them coincide in two main aspects. First, all the existing proposals on the Anthropocene are based on environmental criteria, rather than on stratigraphic grounds, and prioritize the definition of a starting date for this new epoch over other formal sratigraphic requirements. So defined, the Anthropocene is more a historical phase than a stratigraphic unit and, therefore, the use of a formal stratigraphic term ending in -cene is not appropriate (Finney \& Edwards, 2016). Second, it seems universally accepted and taken for granted that the new stratigraphic unit required to account for the human influence on the Earth system should be a series/epoch, albeit nobody has provided a reason for this, not even Crutzen \& Stoermer (2000), who coined the term. Head \& Gibbard (2015) discussed the possibility of the Anthropocene as a stage or substage of the Holocene epoch, in which case the appropriate name would be "Anthropocenian".

The term "Anthropozoic" was coined, described and characterized by Stoppani (1873) in the late $19^{\text {th }}$ century, almost 130 years before the Anthropocene was formulated. However, the "Anthropozoic" has sparked little interest among stratigraphers and is commonly mentioned merely as an anecdotic historical datum, without further descriptions and discussions. For example, Crutzen \& Stoermer (2000) mentioned that the Anthropozoic era was proposed by 
Stoppani (1873), who considered humankind as a "new telluric force which in power and universality may be compared to the greater forces of earth". However, Stoppani did much more than that, as he dedicated three chapters (more than 120 pages) of his Corso di Geologia (Geology Course) to defining, characterizing and subdividing his Anthropozoic era. The low popularity of the Anthropozoic proposal is likely due to two main reasons. First, Stoppani wrote in Italian, and only a few partial English and Spanish translations of some relevant paragraphs exist (e.g., Turpin \& Federighi, 2012; Federighi, 2013; Rull, 2018b). Second, Stoppani was deeply anti-Darwinian and based the new era on the divine creation of Man who would have received God's mandate to populate and dominate the Earth (Hamilton \& Grinevald, 2015). However, in strictly stratigraphic terms, Stoppani provided the necessary elements for the Anthropozoic to be easily rebuilt into a proposal for a new era within the modern chronostratigraphic rules of the ICS, as is shown in this paper.

This paper is based on the original Italian text and summarizes Stoppani's ideas on the Anthropozoic, subdivided into four main conceptual sections: (i) the arguments for the definition of the Anthropozoic era, (ii) the stratigraphic framework in which the new era was proposed, (iii) the sedimentary record and the stratigraphic markers considered, and (iv) the chronology and the subdivisions of the eventual new era. This is called Stoppani's Anthropozoic proposal (SAP) here. The main weaknesses of SAP are discussed and resolved using the intellectual and technological developments of the last century, notably the evolutionary theory applied to humans and radiometric and paleomagnetic dating techniques. The resulting proposal is called the updated Anthropozoic proposal (UAP) and is considered robust enough to be further developed toward an eventual proposal for formalization by the ICS/IUGS. This paper uses mainly geochronological units (era, period, epoch) to facilitate nonspecialist reading.

\section{Stoppani's Anthropozoic proposal (SAP)}

The Italian geologist and priest Antonio Stoppani (1873) (Fig. 2) gathered the legacy of some pioneering naturalists and environmentalists and produced a synthetic view of the new era that he envisaged: the Anthropozoic. The idea of a geological time unit specific for the transformation of Earth by human actions seems to be as old as geology (Lewis \& Maslin, 2018), but the use of the term "anthropozoic" for such time unit dates from the mid-19 century. The Welsh geologist and theologist Thomas Jenkyn (1854) called "anthropozoic" the rocks formed since the initial peopling of the Earth, whereas the Irish geologist and priest Samuel Haughton (1856) used the same term to name the epoch (sic) in which we live, which started with the creation of humans. The concern about the potential environmental consequences of human activities also dates back several centuries (Lewin \& Maslin, 2018), but one of the most influential authors in this matter was the American diplomat and philologist George Marsh, who has been considered the pioneer of modern environmentalist and conservationist movements. In his book entitled "Man and Nature", Marsh (1864) catalogued the damages caused by humans on ecosystems and urged people to adopt more responsible attitudes, given the high transformative capacity of human activities. Some years later, the German zoologist Ernst Haeckel (1868) used the term "anthropozoic period" to define the "era of man", which he considered to be equivalent to the "quaternary", characterized by "the development and dispersal of the human organisms and their culture". According to Kutschera \& Farmer (2020), the term "Anthropozoic" was of current use when Stoppani (1873) - likely influenced by Marsh, who lived in Italy for some time - proposed that the human impacts on Earth were evident, extensive and intensive enough to define a new geological era that he called the Anthropozoic era. 


\section{Stratigraphic framework}

Before analyzing Stoppani's Anthropozoic idea and its potential geological implications, it is necessary to be aware of the stratigraphical framework in which the concept was conceived, in comparison with the present ICC (Fig. 1). Stoppani published his Corso di Geologia a couple of decades after the publication of the first hierarchical fossil-based chronostratigraphic chart by Charles Lyell (1855), which was the more accepted at the time. It should be noted that, in those times, there was no an international organization like the present ICS dedicated to formalizing and unifying the stratigraphic units. Lyell subdivided the Phanerozoic into the Paleozoic, or the Primary Era, and the Neozoic, which contained the Secondary and the Tertiary eras. The Secondary Era or Mesozoic was subdivided into three units: Triassic, Jurassic and Cretaceous. The Tertiary Era or Cainozoic (also Cenozoic) contained the Eocene, the Miocene and the Pliocene. The more recent times were designated by Lyell as Post-Tertiary rather than Quaternary, albeit this term had already been introduced by Desnoyers (1829) a few decades ago. It should also be highlighted that absolute ages in millions of years before present $(\mathrm{Ma})$ for the boundaries between the different stratigraphic units were still unavailable since radiometric dating was not invented until the early $20^{\text {th }}$ century (Boltwood, 1907) and was not firmly established until the 1930s (Dalrymple, 1994). Additionally, the present differentiation between chronostratigraphic units (erathem, system, and series) and the corresponding geochronological units (era, period, and epoch) was not standardized. Stoppani used almost the same stratigraphic framework as Lyell, except for the most recent part, where he differentiated the Neozoic Era, characterized by the Quaternary glaciations, and the Anthropozoic Era, characterized by the geological manifestations of human activities (Fig. 3).

\section{The Anthropozoic concept}

Stoppani (1873) started the first chapter dedicated to the Anthropozoic by recognizing that the rock formations representing this new era are for most geologists just an appendix to the Quaternary formations that characterize the Neozoic era. Thus, the definition of a new era on the basis of such tenuous sedimentary evidence, in comparison to former eras, would scandalize many geologists. However, according to the author, the important thing is not the duration of the time intervals, but rather the importance of what happened in them, and the inception of humans (the creation of Man, according to Stoppani) represented the introduction of a new element with a strength unknown to ancient worlds. Then, the author pointed out that this was important not only in intellectual and moral terms but also in physical terms, since humans constituted a new telluric force that, with its strength and universality, does not pale in the face of the greatest forces of the globe. Later, Stoppani remarked that even though we are only in the beginning of the new era, humans' footprints on Earth are already deep and he mentioned some examples of how human activities have challenged the natural laws, have modified the geological processes and, therefore, have participated in the design or rocks that are currently under formation.

Among other examples, the author mentioned the huge extension of cultivated lands in comparison with those that still remain untouched, if any. He also highlights the engineering works that have changed the natural water courses and have reduced or eliminated the alluvial expansions, thus modifying the sedimentary patterns. Mining activities have destroyed entire mountains and have excavated countless galleries to extract and deplete in a few years what nature has taken millions of years to build up. The construction of big cities and the associated communication infrastructures progressively replace the land due to the manifestations of human industry. Not even the sea escapes human domination as littoral environments are constantly modified by the construction of dams and the drying out of 
littoral lagoons to gain arable land. The atmosphere is also modified by the emissions generated by industry and by fires. In addition to the external visible effects that were mentioned by Stoppani, he also emphasized that the residues resulting from human activities have also start to accumulate following the stratigraphic laws. It is already possible to identify and analyze rocks of human origin and to differentiate their strata according to the different cultures that have generated them. The author emphasized that it was already possible to study series of strata where the history of human generations can be read, just as the history of former marine faunas preserved in rocks of marine origin provided an account of the Earth's history. Examples of these anthropogenic rocks are archaeological sites, which contain not only fossils but also tools and other remains of diverse materials and styles that are witnesses of past cultural changes. Stoppani named the assemblage of all products resulting from human activities as "human relics". Recently, Zalasiewicz et al. (2017c), as part of their Anthropocene proposal, extended the number and variety these human relics under the name of "physical technosphere". This extended list is the result of more than a century of technological developments and the intensification of the human impacts on Earth, but the idea remains the same.

\section{Sedimentary record and stratigraphic markers}

After proclaiming the Anthropozoic era and introducing its main features, Stoppani focused on the geological formations that should contain the first human traces and on the nature of these human footprints. For this author, the first sedimentary evidence of human presence/activity marks the onset of the Anthropozoic. He first pointed out that formations containing human traces should be almost exclusively terrestrial, very recent and rather superficial. According to this author, the most suitable candidates to represent the Anthropozoic would be the following: archaeological sites; landslides; recent lacustrine and marine sediments; sediments from recent floods; deltaic, mash and other littoral sediments; peat bogs and similar deposits; guano and other recent deposits of animal origin; moraines and other recent glacial deposits; recent volcanic sediments and raised marine formations recently deposited. The AWG has also recently updated the list of possible new-forming sediments where one can find traces of human presence and/or activity using more recent technological advances (Waters et al., 2018).

According to Stoppani, these formations should meet several stratigraphic, mineralogical and paleontological criteria. Stratigraphically, these deposits should have overly Neozoic sediments. Additionally, the mineralogy of the Anthropozoic deposits should be consistent with the mineralogy of the surrounding terrain from which they proceed. Paleontologically, the fossils contained in the sediments should correspond to the genera of still living fauna and flora. The most characteristic of these fossils are of human origin, either in the form of proper human remains (notably bones) or of human-made artifacts (human industry). With these considerations, Stoppani set the stage for a formal definition of the Anthropozoic in stratigraphic terms by identifying possible stratotypes and clearly defining the required stratigraphic markers. This is a crucial development and is required to transform the idea of a new unit of Earth's history based on human impacts into a new stratigraphic unit characterized by the geological manifestations of this anthropogenic influence.

\section{Chronology}

Once the concept of the Anthropozoic, its possible representative formations and their differential stratigraphic markers were clear, Stoppani addressed the main chronological issues, emphasizing the beginning of the new era. The author emphasized that, in addition to human bones, other traces are available to record human presence such as weapons, tools, 
constructions, work remnants, and industrial and artistic products, which represent an advantage. However, establishing the time of the first human appearance on Earth was still a drawback, which was insurmountable for the moment. This difficulty comes from the cosmopolitan distribution of humans in contrast with animals (the beasts, according to Stoppani), which have more restricted geographical distributions. Therefore, in the case of humans, it is more difficult to establish the time and the place of the origin (the cradle) of the species. Stoppani mentioned that linguistic, archaeological and historical evidence seemed to indicate central Asia, specifically the Aralo-Caspian region, as the most likely region of origin, from where humans dispersed to all the continents. However, the geological evidence was still insufficient to support this view. At that time, the main body of available geological evidence came from Europe, mainly from the Mediterranean region. Therefore, Stoppani focused on the origin of Europeans, that is, on the European Anthropozoic, to further try to extend the concept abroad.

First, Stoppani attempted to establish that former proposals about a potential Tertiary or Neozoic (i.e., glacial) origin of humans were unfounded. According to this author, the search for the "Tertiary man" or the "glacial man", in their own words, was a waste of time, and the geological evidence provided for such hypotheses was questionable, even ridiculous in some cases. After a detailed analysis of this evidence and its dismissal as proof of human existence, Stoppani claimed that, in Europe, the first traces of undoubtedly human origin were postglacial, that is, post-Neozoic and, therefore, the most primitive Europeans were the Archaeolithic ones. The conclusion was that humans are the youngest of the living species, although an absolute age could not be specified due to the lack of reliable calculations. Another conclusion was that only one human species existed and the Darwinian theory of evolution, according to which humans descended from apes and further evolved, was unsupported. From this point onward, Stoppani passed the baton to archaeology, ethnography and linguistics as the disciplines suited to study the development of human culture. In this context, Stoppani subdivided the Anthropozoic era into the prehistoric and the historic epochs. The prehistoric epoch was further subdivided into the stone age, containing the archaeolithic (now paleolithic) and the neolithic, and the bronze age. The historical epoch was characterized by the iron age. Therefore, Stoppani adopted the available archaeological subdivisions for the history of humankind as the Anthropozoic stratigraphic units.

Regarding the duration of the Anthropozoic, Stoppani contended that it was an enigma since the end of this era could not be predicted at all. He emphasized that the Anthropozoic was not a matter of the handful of centuries that have been (which could be taken as an indication of the temporal framework that Stoppani had in mind), but of those that will be. In other words, this new era was, for Stoppani, a bet on the future. To illustrate this point, the author proposed a future hypothetical Earth devoid of humans after our extinction as a species, which would be visited by intelligent extraterrestrial creatures. He asked whether it would be possible for these intelligent beings to reconstruct the history of our time on the basis of the geological evidence. Stoppani responded that they would be able to do this but only if they considered the new element that is the human spirit. For the author, these future geologists, in their attempt to study the geology of our times, would end up narrating the history of human intelligence.

\section{Summary}

The SAP may be summarized in the following points: (i) there is enough evidence for the definition of the Anthropic era on the basis of the human footprint on Earth and its geological expressions; (ii) the Anthropozoic era succeeded the Neozoic era, characterized by the Quaternary glaciations, and occurred after the Tertiary era; (iii) the rocks representing the 
Anthropozoic era are recent superficial sediments and mostly terrestrial; (iv) in these sediments, the stratigraphic markers of the Anthropozoic era are human bones and/or tools, constructions and other manifestations of anthropogenic origin; $(v)$ the onset of the Anthropozoic era is marked by the first appearance of anthropogenic markers of this type; and (vi) the Anthropozoic era is still in construction and its duration and end cannot be predicted. The weak points of the SAP are the dismissal of human evolution and the lack of a reliable chronology based on radiometric/paleomagnetic dating. The second drawback was unavoidable at Stoppani's times, but the Darwinian view of biological evolution, in general, and of human evolution, in particular, had already been published (Darwin, 1859, 1871). However, Stoppani, as a catholic priest, refused this view and considered that the inception of our species on Earth was the result of God's creation.

\section{The updated Anthropozoic proposal (UAP)}

The updated Anthropozoic proposal discussed here recovers the initial stratigraphic ideas of Stoppani (1873) regarding the Anthropozoic era and adds the new information provided by radiometric and paleomagnetic dating and human evolution. Several morphological and etiological features (e.g., bipedalism, the use of hands, increased brain size, reduced canine teeth, articulate communication, capacity for making arms and tools and the mastery of fire, among others) made up a singular evolutionary package that enabled the emergence of a new, distinct lineage of primates called humans, represented by the first Homo species ( $H$. habilis and $H$. rudolfensis) (Shultz et al., 2012; Maslin et al., 2015). According to Head \& Gibbard (2015), the emergence of the genus Homo coincided with the beginning of the Pleistocene at approximately $2.6 \mathrm{Ma}$ (Fig. 1). Indeed, the oldest records of human fossils - corresponding to the first Homo species - and the first records of human-made stone tools were found in the East African rift and date back to 2.6-2.4 Ma (Deino et al., 2006). Therefore, the base of the Anthropozoic era might be placed at the base of the Quaternary, defined by the GSSP of the Gelasian stage, at $2.588 \mathrm{Ma}$ (Head et al., 2008). This would be consistent with the initial idea of Haeckel (1868) and also with the recent proposal of Williams et al. (2015), according to whom the magnitude of the anthropogenic impacts on the Earth system has largely transcended the scale of a geological epoch. Indeed, these authors defined three main stages in the development of the biosphere, namely, the microbial stage ( 3500 to $650 \mathrm{Ma}$ ), the metazoan stage ( 650 to $2.6 \mathrm{Ma}$ ) and the Anthropocene stage (2.6 Ma onward, accelerating from 14,000 $\mathrm{yr} \mathrm{BP}$ ). These authors considered that the Anthropocene biosphere differs significantly from that of previous stages and their unique features "may herald a new era in the planet's history that could persist over timescales" (Williams et al., 2015). Interestingly, these authors, some of whom belong to the AWG, situated the beginning of what they call the "Anthropocene biosphere" at the beginning of the Quaternary, rather than at the end of the Holocene, and considered that this new biosphere could mark a new era, rather than an epoch.

Defined in this way, the Anthropozoic becomes a major biostratigraphic unit or biozone (Murphy \& Salvador, 1999) characterized by the presence of the first human species, which is a qualitative stratigraphic marker that differentiates the new era, i.e., the human era, from the Cenozoic characterized by the appearance of the first fossil mammals. The use of qualitative fossil markers to define stratigraphic units has been a common practice since the $1800 \mathrm{~s}$ and is one of the main bases for the current ICC units (Lucas, 2018). In addition, chronological correlations based on human fossils and tools are common and are considered a reliable dating method that enables correlation among rocks worldwide. Contrastingly, the Anthropocene may be considered as the expression of a quantitative development based on the recent history of the modern global society whose stratigraphic expression is still to be established (Waters et al., 2018).The UAP also circumvents the drawback of the short duration of the SAP. Indeed, Stoppani thought on a century-scale regarding the duration of the 
Anthropozoic and relied on the future for its full development. As pointed out by Finney \& Edwards (2016), the stratigraphy, as a science, is concerned with the past rather than with the future and a unit based on future expectancy cannot be formalized. The same is valid for the current status of the Anthropocene proposal, where this epoch has barely 70 years of existence. In the UAP framework, the Anthropozoic era already has a duration of 2.58 million years and will persist until human extinction, which will also signify the end of Geology as we know it (Rull, 2016a; 2020). Another advantage of the UAP is that it has been defined according to the rules of the ISG, which prioritizes the stratigraphic evidence for the definition of a new chronostratigraphic unit. In other words, the UAP (and also the SAP) arises from a stratigraphic necessity, which is the correct scientific procedure, instead of a historical concept, as it occurs in the Anthropocene proposal (Finney \& Edwards, 2016). In addition, the UAP is relatively easy to apply to the current ICC and is less traumatic than the current Anthropocene proposal since it only requires the splitting of the current Cenozoic era into two eras based on sound qualitative biostratigraphic criteria with no further chronostratigraphic and geochronologic modifications in the corresponding periods and epochs (Compare Figs. 1 and 4). Moreover, the Anthropozoic era could have nomenclatural priority, as it was named, described and characterized before the Anthropocene epoch, although none has been formalized. Therefore, it seems reasonable to ask why authors are not proposing a new formal era (the Anthropozoic) after the Cenozoic instead of one more Cenozoic epoch such the Anthropocene to the ICS/IUGS (Rull, 2016b).

It should be emphasized that the UAP framework (Fig. 4) is not incompatible with the definition of a new epoch after the Holocene, characterized by the exacerbated human impact on the Earth system. However, this new epoch might not be called the Anthropocene to avoid confusion with a unit of superior rank, i.e., the Anthropozoic. Other names with the suffix cene should be proposed based on the definition of this eventual new epoch, with special consideration given to its stratigraphic markers. Another advantage of the UAP proposal is that it has room to accommodate eventual future developments, such as, for example, the possible interruption of glacial-interglacial cyclicity. Some models predict that, under the current practices, the atmospheric $\mathrm{CO}_{2}$ concentration could increase by $2 \mathrm{x}$ to $8 \mathrm{x}$ in the next centuries and that this would cause the cessation of the glacial-interglacial cyclicity for at least one million years, if not indefinitely (Haqq-Misra, 2014). More recently, a group of scientists, including a number of AWG members, warned about the possibility of reaching an irreversible threshold that would mean the end of glacial-interglacial cyclicity and the beginning of a new state similar to a greenhouse or a hothouse Earth. This new state would be characterized by high atmospheric $\mathrm{CO}_{2}$ concentrations, high temperatures, little difference between eventually ice-free poles and the equator, and high sea levels (Steffen et al., 2018). According to these authors, such a state would be attained with a global average temperature increase of only $2^{\circ} \mathrm{C}$, which could be enough to provoke a cascade effect able to drive the Earth System to a hothouse state (Fig. 5).

The interruption of the glacial-interglacial cyclicity would imply the end of the Quaternary period, which has been defined on the basis of the glacial-interglacial cycles of the last $2.58 \mathrm{Ma}$ (Head et al., 2008); and the Holocene epoch, which has been defined in climatic and anthropogenic terms (Walker et al., 2009). However, the Anthropozoic era, in its updated version, would continue. The new global climatic status of the Earth would require the definition of a new period after the Quaternary, which has been called here "Post-Quaternary" for facility but not as a proposal for a new stratigragphic term (Fig. 6). The term "Anthropogene" (Gerasimov, 1979) is discouraged for the same reason explained above for the term "Anthropocene". If glacial cycles continue, as suggested by other models, the Quaternary may be maintained. In both situations, an eventual unit representing the exacerbation of human influence on the Earth system - a situation which is called here the 
humanized Earth system or HES (Rull, 2016b) - would be an epoch similar to the current Anthropocene proposal (compare Figs. 1 and 6) but with a different name. However, a delay in the next glaciation seems to be unavoidable under the current trend of atmospheric $\mathrm{CO}_{2}$ increases (Tzedakis et al., 2012; Herrero et al., 2014). Therefore, the solution will be a matter of millennia or tens of millennia and the situation will be analyzed by future geologists, provided they exist and are still interested in stratigraphy.

Nevertheless, these are only speculations. The truth is that neither the Anthropozoic nor the Anthropocene proposals have yet been submitted to the ICS/IUGS for approval and ratification. This paper has attempted to demonstrate that the updated Anthropocene proposal (UAP) fulfils the requirements to be considered as a sound stratigraphic initiative to be further elaborated and submitted for formalization. This would require little work, in comparison with the current AWG proposal, since the Anthropozoic stratigraphic and chronological features are clear and reasonably well known worldwide. An eventual Anthropozoic proposal could be considered either a competitor of the current Anthropocene proposal or an alternative in the case of this new epoch is not approved.

\section{Conclusions}

The original idea of Stoppani to define the Anthropozoic as a new era (i.e., the human era) based on the presence of human fossils and/or their associated manifestations, complemented by further developments in human evolution and radiometric dating, has led to the so-called updated Anthropocene proposal (UAP). So defined, the base of the Anthropozoic era coincides with the base of the Quaternary, which implies that the Cenozoic would have finished with the Neogene (Fig. 4). This idea is still in an embryonic stage but seems to have the potential to be further developed toward a proposal to the ICS/IUGS for formalization. The main advantages of the UAP are the following: (i) it follows the ISG rules for the definition of chronostratigraphic units based on GSSPs; (ii) it is based on qualitative biostratigraphic criteria, as is usual in many chronostratigraphic units of the ICC; (iii) the base of the Anthropozoic is well dated and coincides with the GSSP that marks the onset of the Quaternary; (iv) the addition of this Anthropozoic era to the current ICC could be done without any modifications to the already existing periods and epochs and their corresponding ages; ( $v$ ) the definition of the Anthropozoic era in the way proposed here is not incompatible with the proposal of a stratigraphic unit following the Holocene, characterized by the exacerbation of human impacts on the Earth system (albeit this epoch should not contain the prefix anthropo- to avoid confusion); and (vi) it is robust enough to accommodate a range of potential scenarios resulting from the anthropogenic increase in the atmospheric $\mathrm{CO}_{2}$ concentration. The creation of a commission for the full development of the updated Anthropozoic proposal and its submission to the ICS/IUGS for formalization is encouraged. 


\section{References}

Boltwood, B. 1907. The ultimate disintegration products of the radio-active elements. Part II. The disntegration products of uranium. American Journal of Science 23, 77-88.

Cohen, K.M., Finney, S.C., Gibbard, P.L., Fan, J.-X. 2013. The ICS International Chronostratigraphic Chart. Episodes 36, 199-204.

Crutzen, P.J., Stoermer, E.F. 2000. The 'Anthropocene'. IGBP Newsletter 41, 17-18.

Dalrymple, G.B. 2001. The age of the earth in the twentieth century: a problem (mostly) solved. Geological Socity of London Special Publication 190, 205-221.

Darwin, C. 1859. The Origin of Species by Means of Natural Selection. John Murray, London. Darwin, V. 1871. The Descent of Man, and Selection in Relation to Sex. John Murray, London. Deino, A.L., Kingston, J.D., Glen, J.M., Edgar, R.K., Hill, A. 2006. Precessional forcing of lacustrine sedimentation in the late Cenozoic Chemeron Basin, Central Kenya Roft, and calibration of the Gauss/Matuyama boundary. Earth and Planeteray Science Letters 247, 41-60.

Desnoyers, J. 1829. Observations sur un ensemble des dépòts marines plus récents que les terraines tertiaries du basin de la Seine, et constituent une formation géologique distincte: précédés d'une aperçu de la non-simultanéité des bassins tertiaries. Annales des Sciences Naturelles 16, 171-124, 402-491.

Edwards, L.E. 2015. What is the Anthropocene? EOS 96, 6-7.

Federighi, V. 2013. The Anthropozoic Era: Excerpts from Corso di Geologia. SCAPEGOAT 5, 346353.

Finney, S.C. 2014. The 'Anthropocene' as a ratified unit of the ICS International Stratigraphic Chart: fundamental issues that must be adressed by the Task Group. In: Waters, C.M., Zalasiewicz, J., Williams, M., Ellis, E., Snelling, A.M. (eds.), A Stratigraphical Basis for the Anthropocene. Geological Society of London, London, pp. 23-28.

Finney, S.C., Edwards, L.E. 2016. The "Anthropocene" epoch: scientific decision or political statement? GSA Today 26, 4-10.

Gerasimov, I.P. 1979. Anthropogene and its major problem. Boreas 8, 23-30.

Gibbard, P.L., Walker, M.J.C. 2014. The term 'Anthropocene' in the context of formal geological classification. In: Waters, C.M., Zalasiewicz, J., Williams, M., Ellis, E., Snelling, A.M. (eds.), A Stratigraphical Basis for the Anthropocene. Geological Society of London, London, pp. 29-37.

Haeckel, E. 1868. Natürliche Schöpfungsgeschichte. Georg Reimer, Berlin.

Hamilton, C., Grinevald, J. 2015. Was the Anthropocene anticipated? Anthropocene Review 2, 59-72. Journal of Advances in Modeling Earth Systems 6, 950-955.

Haqq-Misra, J. 2014. Damping of glacial-interglacial cycles from anthropogenic forcing. Journal of Advances in Modelling of the Earth System 6, 950-955.

Haughton, S. 1865. Manual of Geology. Longman, London.

Head, M.J., Gibbard, P. 2015. Formal subdivision of the Quaternary System/Period: past, present and future. Quaternary International 383, 4-35.

Head, M.J., Gibbard, P., Salvador, A. 2008. The Quaternary: its character and definition. Episodes 31, 234-238.

Herrero, C., García-Olivares, A., Pelegrí, J.L. 2012. Impact of Anthropogenic CO2 on the next glacial cycle. Climatic Change 122, 283-298.

Jenkyn, T.W. 1854. Lessons in Geology XLIX. Chapter V. On the classification of rocks, section IV. On the tertiaries. Popular Educator 4, 312-316.

Kutschera, U., Farmer, S. 2020. Ernst Haeckel, ancient forests, and the Anthropocene. Plant Signaling \& Behavior, doi 10.1080/15592324.2020.1719313.

Lewis, S.L., Maslin, M.A. 2015. Defining the Anthropocene. Nature 519, 171-180.

Lewis, S.L., Maslin, M.A. 2018. The Human Planet. How We Created the Anthropocene. Yale University Press, New Haven. 
Lucas, S.G. 2018. The GSSP method of chronostratigraphy: a critical review. Frontiers in Earth Science 6, 191.

Lyell, C. 1855. A Manual of Elementary Geology. John Murray, London.

Marsh, G.P. 1864. Man and Nature; or Physical Geography as Modified by Human Action. Charles Scribner, New York.

Maslin, M.A., Shultz, S., Trauth, M.H. 2015. A synthesis of the theories and concepts of early human evolution. Philosophical Transactions of the Royal Society B 370, 20140064.

Murphy, M.A., Salvador, A. 1999. International Stratigraphic Guide - an abridged version. Episodes 22, 255-271.

Ruddiman, W.F. 2003. The anthropogenic greenhouse era began thousands of years ago. Climatic Change 61, 261-293.

Ruddiman, W.F. 2013. The Anthropocene. Annual Reviews of Earth and Planetary Sciences 41, 45-68.

Rull, V. 2016a. The 'Anthropocene': a requiem for the Geologic Time Scale? Quaternary Geochronology 36, 76-77.

Rull, V. 2016b. The Humanized Earth System. Holocene 26, 1513-1516.

Rull, V. 2018a. What if the 'Anthropocene' is not formalized as a new geological series/epoch? Quaternary 1, 24.

Rull, V. 2018b. El Antropoceno. Editorial CSIC, Madrid.

Rull, V. 2020. Quaternary Ecology, Evolution, and Biogeography. Academic Press, London.

Shultz, S., Nelson, E., Dunbar, R.I.M. 2012. Hominin cognitive evolution: identifying patterns and processes in the fossil and archaeological record. Philosophical Transactions of the Royal Society B 367, 2130-2140.

Steffen, W., Rockström, J., Richardson, K., Lenton, T.M., Folke, C., Liverman, D., Summerhayes, C.P., Barnosky, A.D., Cornell, S.E., Crucifix, M., Donges, J.F., Fetzer, I., Lade, S.J., Scheffer, M., Winkelmann, R., Schellnhuber, H.J. 2018. Trajectories of the earth system in the Anthropocene. Proceedings of the National Academy of Sciences USA 115, 8252-8259.

Stoppani, A. 1873. Corso di Geologia. Volume II: Geologia Stratigrafica. G. Bernardoni e G. Brigola Editori, Milano.

Turpin, E., Federighi, V. 2012. A new element, a new force, a new input: Antonio Stoppani's Anthropozoic. In: Ellsworth, E., Kruse, J. (eds.), Making the Geologic Now. Punctum Books, New York, pp. 34-41.

Tzedakis, P.C., Channel, J.E.T., Hoddell, D.A., Kleiven, H.F., Skinner, L.C. 2012. Determining the natural length of the current interglacial. Nature Geoscience 5, 138-141.

Walker, M., Johnsen, S., Rasmussen, S.O., Popp, T., Steffensen, J.-P., Gibbard, P., Hoek, W., Lowe, J., Andrews, J., Björk, S., Cwynar, L.C., Hughen, K., Kershaw, P., Kromer, B., Litt, T., Lowe, D.J., Nakagawa, T., Newnham, R., Scwander, J. 2009. Formal definition and dating of the GSSP (Global Stratotype Section and Point) for the base of the Holocene using the Greenland NGRIP ice core, and selected auxiliary records. Journal of Quaternary Science 24, 3-17.

Walker, M., Gibbard, P., Lowe, J. 2015. Comment of "When did the Anthropocene begin? A mid-twentieth century boundary is stratigraphically optimal" by Jan Zalasiewicz et al. (2015), Quaternary International, 383, 196-203. Quaternary International 383, 204-207.

Waters, C.M., Zalasiewicz, J., Williams, M., Ellis, E., Snelling, A.M. 2014. A Stratigraphical Basis for the Anthropocene. Geological Society of London, London.

Waters, C.N., Zalasiewicz, J., Summerhayes, C.P., Barnosky, A.D., Poirier, C., Gałuszka, A., Cearreta, A., Edgeworth, M., Ellis, E.C., et al. 2016. The Anthropocene is functionally and stratigraphically distinct from the Holocene. Science 351, aad2622.

Waters, C.N., Zalasiewicz, J., Summerhayes, C.P., Fairchild, I.J., Rose, N.L., Loader, N.J., Shotuk, W., Cearreta, A., Head, M.J., Syvitski, J.P.M., et al. 2018. Global Boundary Stratotype Section and Point (GSSP) for the Anthropocene Series: where and how to look for potential candidates. Earth-Science Reviews 178, 379-429. 
Williams, M., Zalasiewicz, J., Haff, P.K., Schwärgel, C., Barnosky, A.D., Ellis, E.C. 2015. The Anthropocene biosphere. Anthropocene Review 2, 196-219.

Zalasiewicz, J., Waters, C.N., Wolfe, A.P., Barnosky, A.D., Cearreta, A., Edgeworth, M., Ellis, E.C., Fairchild, I., Gradstein, F.M., Grinevals, J., et al. 2016. Finney and Edwards article. GSA Today 27, e36-e37.

Zalasiewicz, J., Waters, C.N., Summerhayes, C.P., Wolfe, A.P., Barnosky, A.D., Cearreta, A., Crutzen, P., Ellis, E., Fairchild, I.J., Gałuszka, A., et al. 2017a. The Working Group of the Anthropocene: summary of evidence and interim recommendations. Anthropocene 19, 55-60.

Zalasiewicz, J., Waters, C.N., Wolfe, A.P., Barnosky, A.D., Cearreta, A., Edgeworth, M., Ellis, E.C., Fairchild, I.J., Gradstein, F.M., Grinevald, J., et al. 2017b. Making the case for a formal Anthropocene Epoch: analysis of the critiques. Newslwtter on Stratigraphy 50, 205-226.

Zalasiewicz, J., Williams, M., Waters, C.N., Barnosky, A.D., Palmesino, J., Rönnskog, A.-S., Edgeworth, M., Neal, C., Cearreta, A., Ellis, E.C., et al. 2017c. Scale and diversity of the physical technosphere: a geological perspective. Anthropocene Review 4, 9-22. 


\section{Figure captions}

Figure 1. Comparison between the Cenozoic subdivision in the latest version of the International Chronostratigraphic Chart (Cohen et al., 2013) and in the current proposal of the Anthropocene Working Group (Zalasiewicz et al., 2017a). All ages are in million years before the present (Ma), except the base of the Anthropocene, which is in calendar years of the Common Era (CE).

Figure 2. Drawing of Antonio Stoppani (1824-1891) in his office during the last days of his life. Downloaded from https://commons.wikimedia.org/wiki/File:Antonio Stoppani latelife.jpg

Figure 3. Comparison between the stratigraphic charts of Lyell (1855) and Stoppani (1873) from the Cenozoic (Tertiary) onward. The Anthropozoic era is highlighted in blue.

Figure 4. Updated Anthropozoic proposal combining the stratigraphic ideas of Stoppani (1873) with the new developments in and radiometric dating and in human evolution, and the concept of the "Anthropocene biosphere" (Williams et al., 2015).

Figure 5. Graphical representation of the hypothetical interruption of the glacial-interglacial cycles by a $2^{\circ} \mathrm{C}$ increase in the average global temperature. Glacial-interglacial cycles are represented by the blue line. The red line represents what has happened since the Industrial Revolution and what might happen in the future if we go over the $2^{\circ} \mathrm{C}$ threshold. The Earth System (blue spheres) would be still be able to stabilize in the present state (green line) if we were to stay below this limit. Redrawn from Steffen et al. (2018).

Figure 6. Two possibilities for the definition of a new stratigraphic unit based on the recent exacerbation of human impact on the earth system, a situation called here the humanized Earth system or HES (Rull, 2016b), under the updated Anthropocene proposal (UAP) described in this paper. If the Quaternary glacial-interglacial cyclicity is maintained, then the unit representing the HES proposal would coincide with the current Anthropocene proposal (Fig. 1) but a different term should be coined. If the glacial-interglacial cyclicity is interrupted, as proposed by some models (e.g., Fig. 5) then a new period should be defined after the Quaternary, starting with the HES. The terms "Post-Quaternary" and "HES" are not proposed here as stratigraphic terms but only as useful descriptors. 
This paper is a non-peer reviewed EarthArXiv preprint

Internartional Chronostratigraphic Chart

\begin{tabular}{|c|c|c|c|}
\hline ERA & PERIOD & $\mathrm{EPOCH}$ & Age (Ma) \\
\hline \multirow{7}{*}{$\begin{array}{l}0 \\
\text { O } \\
\text { O } \\
\frac{0}{0} \\
0\end{array}$} & \multirow{2}{*}{ Quaternary } & Holocene & \multirow{2}{*}{0.0117} \\
\hline & & Pleistocene & \\
\hline & \multirow{2}{*}{ Neogene } & Pliocene & \multirow{2}{*}{$\begin{array}{l}2.58 \\
5.333\end{array}$} \\
\hline & & Miocene & \\
\hline & \multirow{3}{*}{ Paleocene } & Oligocene & \multirow{3}{*}{$\begin{array}{l}23.03 \\
33.9 \\
56.0\end{array}$} \\
\hline & & Eocene & \\
\hline & & Paleocene & \\
\hline
\end{tabular}

Cohen et al. (2013)
Current Anthropocene proposal (AWG)

\begin{tabular}{|c|c|c|c|}
\hline ERA & PERIOD & $\mathrm{EPOCH}$ & Age (Ma) \\
\hline \multirow{8}{*}{$\begin{array}{l}0 \\
\text { ON } \\
O \\
\\
0\end{array}$} & \multirow{3}{*}{ Quaternary } & Anthropocene & \\
\hline & & Holocene & \\
\hline & & Pleistocene & \multirow{3}{*}{$\begin{array}{l}2.58 \\
5.333\end{array}$} \\
\hline & \multirow{2}{*}{ Neogene } & Pliocene & \\
\hline & & Miocene & \\
\hline & \multirow{3}{*}{ Paleocene } & Oligocene & \multirow{2}{*}{$\begin{array}{l}23.03 \\
33.9\end{array}$} \\
\hline & & Eocene & \\
\hline & & Paleocene & \\
\hline
\end{tabular}

Zalasiewicz et al. (2017a)

Figure 1

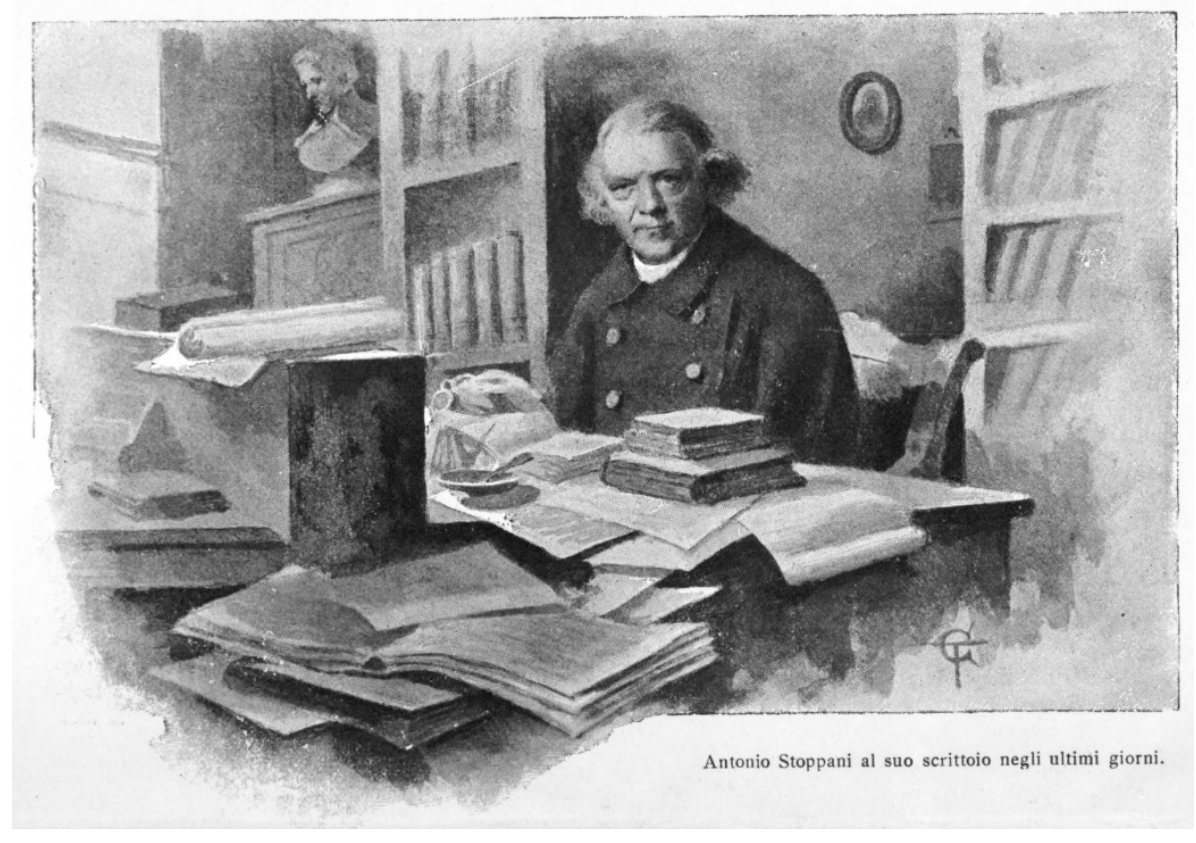

Figure 2 
This paper is a non-peer reviewed EarthArXiv preprint

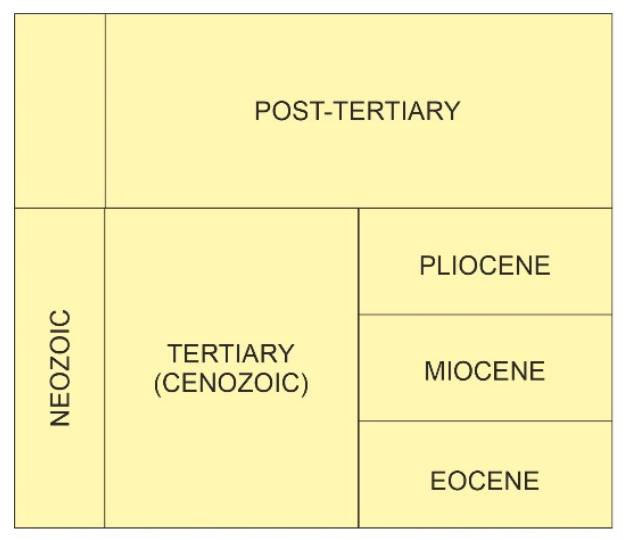

Lyell (1855)

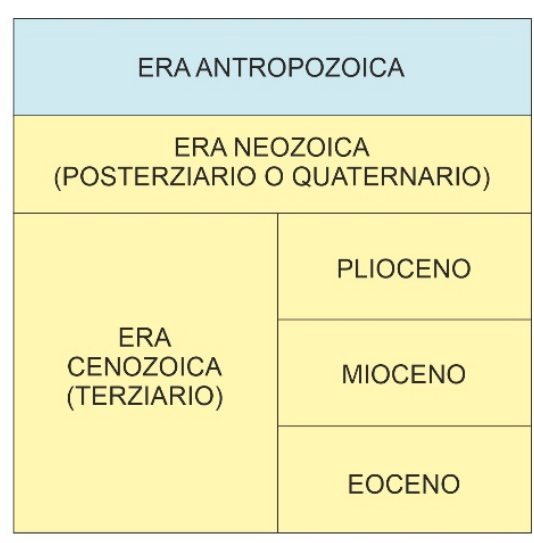

Stoppani (1873)

Figure 3

Updated Anhtropozoic proposal

\begin{tabular}{|c|c|c|c|}
\hline ERA & PERIOD & $\mathrm{EPOCH}$ & Age (Ma) \\
\hline \multirow{2}{*}{ Anthropozoic } & \multirow{2}{*}{ Quaternary } & Holocene & \multirow{2}{*}{0.0117} \\
\hline & & Pleistocene & \\
\hline \multirow{7}{*}{ Cenozoic } & \multirow{3}{*}{ Neogene } & & \multirow{3}{*}{$\begin{array}{l}2.58 \\
5.333\end{array}$} \\
\hline & & Pliocene & \\
\hline & & Miocene & \\
\hline & \multirow{4}{*}{ Paleocene } & Oligocene & 23.03 \\
\hline & & & \multirow{3}{*}{$\begin{array}{l}33.9 \\
56.0\end{array}$} \\
\hline & & Eocene & \\
\hline & & Paleocene & \\
\hline
\end{tabular}

Figure 4 
This paper is a non-peer reviewed EarthArXiv preprint

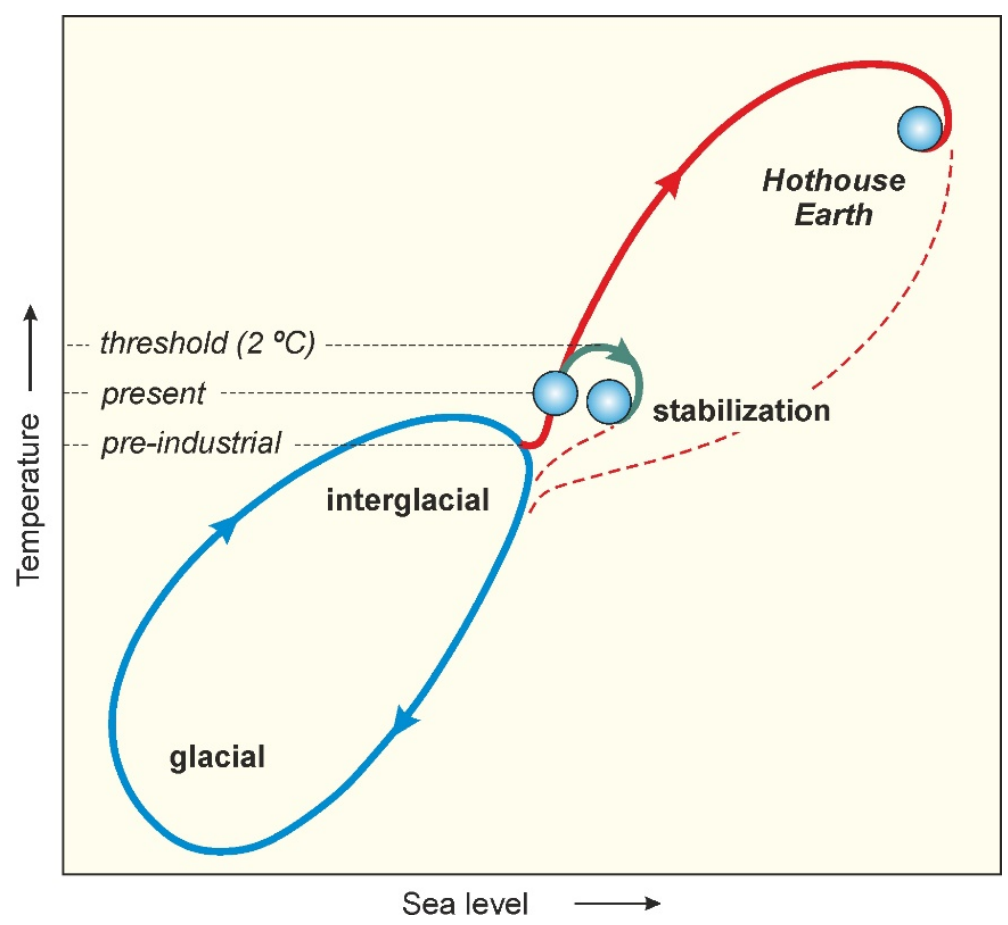

Figure 5

Glacial-interglacial continuity

\begin{tabular}{|c|c|c|c|}
\hline ERA & PERIOD & $\mathrm{EPOCH}$ & Age (Ma) \\
\hline \multirow{3}{*}{ Anthropozoic } & \multirow{3}{*}{ Quaternary } & HES & \multirow{3}{*}{ ? } \\
\hline & & Holocene & \\
\hline & & Pleistocene & \\
\hline \multirow{6}{*}{ Cenozoic } & \multirow{2}{*}{ Neogene } & Pliocene & \multirow{2}{*}{$\begin{array}{l}2.58 \\
5.333\end{array}$} \\
\hline & & Miocene & \\
\hline & \multirow{4}{*}{ Paleocene } & Oliansene & \multirow{4}{*}{$\begin{array}{l}23.03 \\
33.9 \\
56.0\end{array}$} \\
\hline & & 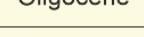 & \\
\hline & & Eocene & \\
\hline & & Paleocene & \\
\hline
\end{tabular}

Glacial-Interglacial cessation

\begin{tabular}{|c|c|c|c|}
\hline ERA & PERIOD & $\mathrm{EPOCH}$ & Age (Ma) \\
\hline \multirow{3}{*}{ Anthropozoic } & Post-Quaternary & HES & \multirow{3}{*}{$\begin{array}{l}0 \\
? \\
0.0117\end{array}$} \\
\hline & \multirow{2}{*}{ Quaternary } & Holocene & \\
\hline & & Pleistocene & \\
\hline \multirow{6}{*}{ Cenozoic } & \multirow{2}{*}{ Neogene } & Pliocene & \multirow{4}{*}{$\begin{array}{l}2.58 \\
5.333 \\
23.03\end{array}$} \\
\hline & & & \\
\hline & \multirow{4}{*}{ Paleocene } & & \\
\hline & & Oligocene & \\
\hline & & Eocene & \multirow{2}{*}{$\begin{array}{l}33.9 \\
56.0\end{array}$} \\
\hline & & Paleocene & \\
\hline
\end{tabular}

Figure 6 